\title{
The Power of Expectations in School Management: Pygmalion Effect
}

\begin{tabular}{ccc}
\hline Article Type & Received Date & Accepted Date \\
Research & 05.04 .2018 & 29.01 .2019 \\
\hline
\end{tabular}

\section{Seda Gündüzalp*}

\author{
Mukadder Boydak Özan ${ }^{* *}$
}

\begin{abstract}
This study aims to discover the pygmalion effect, which suggests to affect a person's expectations from other people on the actions of those people, by taking the opinions of primary school teachers. In order for the study to reach its goal, triangulation technique, which is a mixed method design, has been used. A likert-type five-point scale made up of 18 items and a semi-structured interview form comprising two open-ended questions have been used to acquire data. The scale has applied to take the opinions of teachers working at the schools administered by 25 managers mastering in a postgraduate program without thesis at the Education Management Inspection Planning and Economy Department of Firat University Institute of Education Sciences. The quantitative and qualitative data acquired have been analyzed by means of statistical softwares. It has been concluded from the findings acquired from teachers' views reveal the reality and accuracy of pygmalion effect in the field of education, and show that high expectations pave the way for teachers' motivation, effort, active working, commitment as well as the growth of their enthusiasm. It is seen that high expectations will generally reveal high performance, while low expectations, due to their negative effects on employees, will cause decrease in motivation as well as unwillingness towards the job being done and therefore, a decline or stability in performance.
\end{abstract}

Keywords: Pygmalion effect, expectation, school, management, triangulation.

\footnotetext{
* Dr., Munzur University, Pertek Sakine Genç Vocational School, Departmant of Management and Organization, Tunceli, Turkey. E-mail: sedagunduzalp@munzur.edu.tr, https://orcid.org/0000-0003-3546-5644

${ }^{* *}$ Prof. Dr., Firat University, Faculty of Education, Department of Educational Sciences, Elazığ, Turkey.

E-mail: mboydak@firat.edu.tr, https://orcid.org/0000-0001-5690-6985
} 


\title{
Okul Yönetiminde Beklentilerin Gücü: Pygmalion Etkisi
}

\begin{tabular}{ccc}
\hline Makale Türü & Başvuru Tarihi & Kabul Tarihi \\
Araştırma & 05.04 .2018 & 29.01 .2019 \\
\hline
\end{tabular}

Seda GÜNDÜZALP*

\author{
Mukadder BOYDAK ÖZAN**
}

\begin{abstract}
Öz
$\mathrm{Bu}$ çalışma ile bireylerin çevresindekilere ilişskin oluşturdukları beklenti ve düşüncelerinin onların davranışlarını etkilediği görüşüyle ortaya çıkan pygmalion etkisinin, ilköğretim okullarında görev yapan öğretmenlerin görüşleri alınarak okul ortamındaki yansımasını tespit etmek amaçlanmıştır. Araştırmanın amacına ulaşılabilmesi için karma yöntem tasarımlarından üçgenleme (triangulation) tekniği kullanılmıştır. Verileri elde etmek amacıyla likert tarzında 18 maddeden oluşan beşli derecelendirme şeklinde hazırlanmış bir ölçek ve iki açık uçlu sorudan oluşan yarı yapılandırılmış bir görüşme formu kullanılmıştır. Ölçek Fırat Üniversitesi Eğitim Bilimleri Enstitüsü Eğitim Yönetimi Teftişi Planlaması ve Ekonomisi Anabilimdalı'nda tezsiz yüksek lisans öğrenimi gören 25 yöneticinin görev yaptıkları okullarda çalışan öğretmenlerin görüşleri alınmak üzere uygulanmıştır. Elde edilen nicel veriler ve nitel veriler istatistik programları kullanılarak analiz edilmiştir. Yapılan analizler sonucu elde edilen bulgular eğitim alanında da pygmalion etkisinin gerçekliği ve doğruluğunu açığa çıkarmakta, yüksek beklentinin öğretmelerin motivasyon, çaba, etkin çalışma ve işlerine olan bağlılıklarının yanı sıra işe karşı duydukları isteklerinin artmasına ortam hazırlayacağı; yüksek beklentinin genelde yüksek performansı ortaya çıkaracağı, düşük beklentilerin ise, çalışanlar üzerinde bıraktığı olumsuz etki sebebiyle motivasyonda azalma, yapılan işe karşı isteksizlik ve bunun sonucunda performansta düşüklük veya stabilite gözlemlenebileceğini göstermektedir.
\end{abstract}

Anahtar Sözcükler: Pygmalion etkisi, beklenti, okul, yönetim, üçgenleme

\footnotetext{
* Dr., Munzur Universitesi, Pertek Sakine Genç Meslek Yüksek Okulu, Yönetim ve Organizasyon Bölümü, Tunceli, Türkiye. E-posta: sedagunduzalp@munzur.edu.tr, https://orcid.org/ 0000-0003-3546-5644

${ }^{* *}$ Prof. Dr., Fırat Universitesi, Eğitim Fakültesi, Eğitim Bilimleri Bölümü, Elazı̆̆, Türkiye.

E-posta:mboydak@firat.edu.tr, https://orcid.org/0000-0001-5690-6985
} 


\section{Introduction}

We have expectations about when, where and how someone will behave. While expectations are about "behavioral inclination" sometimes, they can also be about a specific individual at other times. We expect an individual who has behaved aggressively before to behave in the same way in a similar situation. Behind these types of expectations lie our learnings that a past behavior will recur under similar conditions (Demirtaş, 2004). The beliefs and thoughts of a person create a situation which causes the expected behavior to occur. A person expected to be highly successful will probably show a great performance. "I know that you will do the best" or "This may be difficult for you." Such clues pave the way for the behaviors expected. The expectations and thoughts of someone regarding another person may influence the behaviors of that person in the long run (Loftus, 1995).

The effect of expectations has attracted the attention of scientists and brought along the studies on this subject. The effect of expectations is called the "Pygmalion effect" in psychology, and this term goes back to Greek mythology. Pygmalion was the prince of Cyprus who hated women and thought he would never get married. The prince of Cyprus, sculptor Pygmalion, thought that all women were defective and tried to sculpture the ideal woman. This art piece, given the name Galatea by him, was so beautiful that Pygmalion hopelessly fell in love with his own work. He invoked Venus, asking her to make Galatea come to life. Venus fulfilled this wish, and the couple lived happily thereafter (Şenlen, 2008). The psychological studies on this ending define the effect of expectations as the pygmalion effect (Wang, 2000). Taking this effect into consideration, George Bernard Shaw wrote the musical named "My Fair Lady." This musical was demonstrated in 1914 for the first time in London (Shaw, 2004, Prasad, 2013). In George Bernard Shaw's Pygmalion, Eliza Doolittle says the following: "The difference between a lady and a flower girl (except for those things which can be gained by anyone like clothes and speech manners) is not how she behaves, but how she's treated. I shall always be a flower girl to Professor Higgins, because he always treats me as a flower girl, and always will, but I know I can be a lady to you, because you always treat me as a lady" (Murphy et al., 1999). Pygmalion effect is the result of a prophecy that essentially fulfills itself. This effect is not a reaction occurring during a moment of expectation; rather, it is a process made up of self-sufficiency, motivation and reference (Wang, 2000).

Pygmalion effect has been addressed for the first time by Robert Merton (1948), a sociologist, and named 'self fulfilling prophecy' by him. To him, definitions related to a specific phenomenon (prophecies or expectations) become an integral part of that phenomenon after a while, and this affects subsequent developments. The Pygmalion effect takes place in literature also as "basic expectation effect" and "self fulfilling prophecy." This term may be explained with someone demonstrating behaviors in line with other people's (especially those he/she feels inferior to) expectations from him/her after a while (Reynolds, 2007). While the pygmalion effect is an incorrect definition of a situation that brings along a new behavior, in the end it turns a situation which is essentially incorrect into reality (Madran, 2012). It is agreed that the term involves both positive and negative expectations (Chang, 2011). The Pygmalion effect is not only an argument between psychologists and sociologists, but also a term in which pedagogues are interested in (Spitz, 1999). This term may also be explained as follows: when we expect something to happen in a specific way, our expectation will be inclined to ensure that (Rosenthal et al. 1966). Here, it is probable that the expected behavior will be in line with believes and thoughts (Loftus, 1999). 


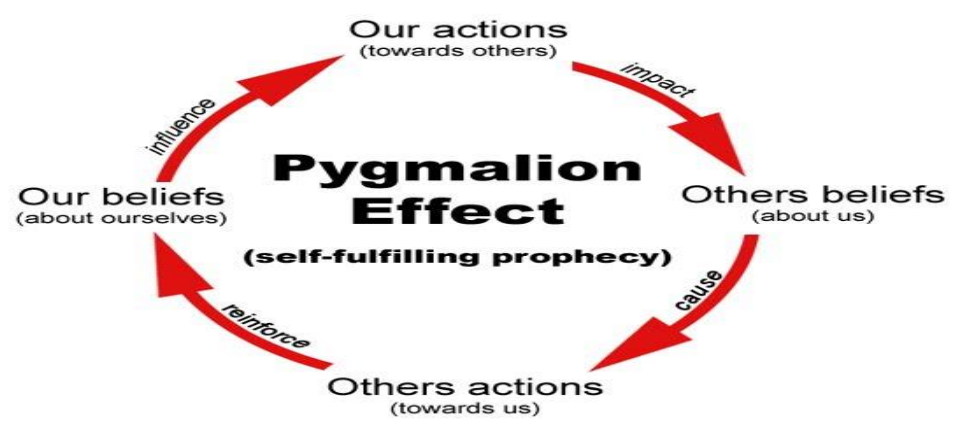

Figure 1. The Pygmalion Effect (Kashen, 2011)

In mid 1960s (when Skinner's behaviorism was popular), Rosenthal and Lenore Jacobson conducted an experimental study on 18 teachers and the students educated by them; they chose equal number of students from each class, and told teachers that these students might improve significantly during the year in terms of intellectuality. They applied an IQ test to students. It was stated that these students, who were in the first ten, were inclined to improve in terms of intelligence level. The same IQ test was applied again at the end of the year. It was seen that the general IQ points of this group of students increased. According to Rosenthal and Jacobson (1968), how and when the teachers said something, their facial expression, body language and even their touch might have conveyed the message to students that the teachers expected high performance from them. Such a communication, together with possible amendments in education techniques, might have helped students learn by changing their self-concepts, their expectations from themselves, their motivations as well as their perception style and talents. There were no difference between the amounts of time spent by teachers on each student; however, it was observed that the quality of relationships was different. There was an improvement in the intelligence levels of the students who were expected to improve thanks to their teachers' expectations in this way. Teachers have high expectations from the students who have high academic levels according to them; therefore, such students achieve academic success. The effect of expectations has been examined within the scope of this study, and it has been concluded that expectations influence success and performance. The effect of teachers' expectations on students is similar to that of leaders' on employees in organizations (Bezuijen et al. 2009). Immediately after the introduction of its effect in classroom environment, the effect of pygmalion has been tested also in organizational environments and recorded in the literature. Since Livingston published a study in which he researched the effect of Pygmalion on management along with some sample cases in the year 1969, Pygmalion effect has become generalizable in fields beyond typical classroom environment (Locke and White, 2000). To him, productivity would be excellent if managers had high expectations. Similarly, if their expectations were low, the productivity would be insufficient. Since the elements of an organization are individuals and groups, it is impossible to ignore the phenomenon of expectation in an organization. The performance managers expect from their inferiors as well as how they treat and communicate the people they are working with substantially affect the performance and career development of such people positively or negatively.

Pygmalion effect in the field of management may be explained majorly with two phenomena. These are leadership behaviors and individual's own expectations from himself/herself. The term pygmalion has an obvious connection with leadership and motivation theories (Locke and White, 2000). How managers treat their inferiors affects their performance. If a manager is stern, rude and inconsiderate, his/her inferiors will be demotivated and this demotivation will cause low performance. On the contrary, if he/she is too indifferent, tolerant and indulgent, his/her inferiors will not try to improve their performance. Both employees and the organization they are working for will suffer in either situation. If the manager is considerate and tolerant where necessary, and if he/she is stern, authoritative but kind when required, motivation and therefore performance will be high. This will be in favor of both the employees and the organization (Bridge, 2003). The employees who are expected to deliver high performance are more motivated to improve themselves than those whose leaders have low expectations from them (Bezuijen et al., 2009). 
In fact, managers generally convey a lot when they think that they are conveying just too little. For example, when they behave secretively and do not say anything, they convey the message that one of the employees has annoyed him/her, or he/she finds one of the employees unsatisfactory. Sometimes, keeping quite conveys negative feelings much more effectively than direct criticism. Indifferent and unclear behaviors usually represent low expectations, and cause low performance. Before they convert into performance, the expectations of management should pass the reality exam. If the inferiors of a manager find his/her expectations unrealistic, they will not be motivated to reach high productivity levels. If they are encouraged to make an effort to attain unreachable goals, they will give up trying in the end, and accept much lower targets than they can really achieve. Managers cannot get rid of the depressing cycle of events caused by low expectations only by hiding their feelings from their inferiors. If managers believe that the performance of their inferiors will be inadequate, it will be almost impossible for them to hide their feelings since the message is generally conveyed without any deliberate action (Livingston, 1969). Successful managers who are aware of this fact try to use their effect on their inferiors' performance positively, and trust both themselves and those around them (Chirayath et al., 2009). These managers expect high performance from people they are working with. There is a linear relation between what is expected from someone and the effort he/she makes to achieve. Therefore, if a manager expects high performance, the performance of those reporting to him/her will be influenced positively. Both employees and the organization they are working for derive benefit out of this, improve, and achieve the best. Less efficient managers do not expect much from their inferiors; therefore, the productivity of their inferiors is generally inclined to decrease. In such cases, both employees cannot advance in their career, and the organization they are working for suffer from low performance (Bridge, 2003). Leaders with high expectations create a supportive environment, and know that the success of employees depend on internal processes, stability and their behaviors (Eden et al., 2000).

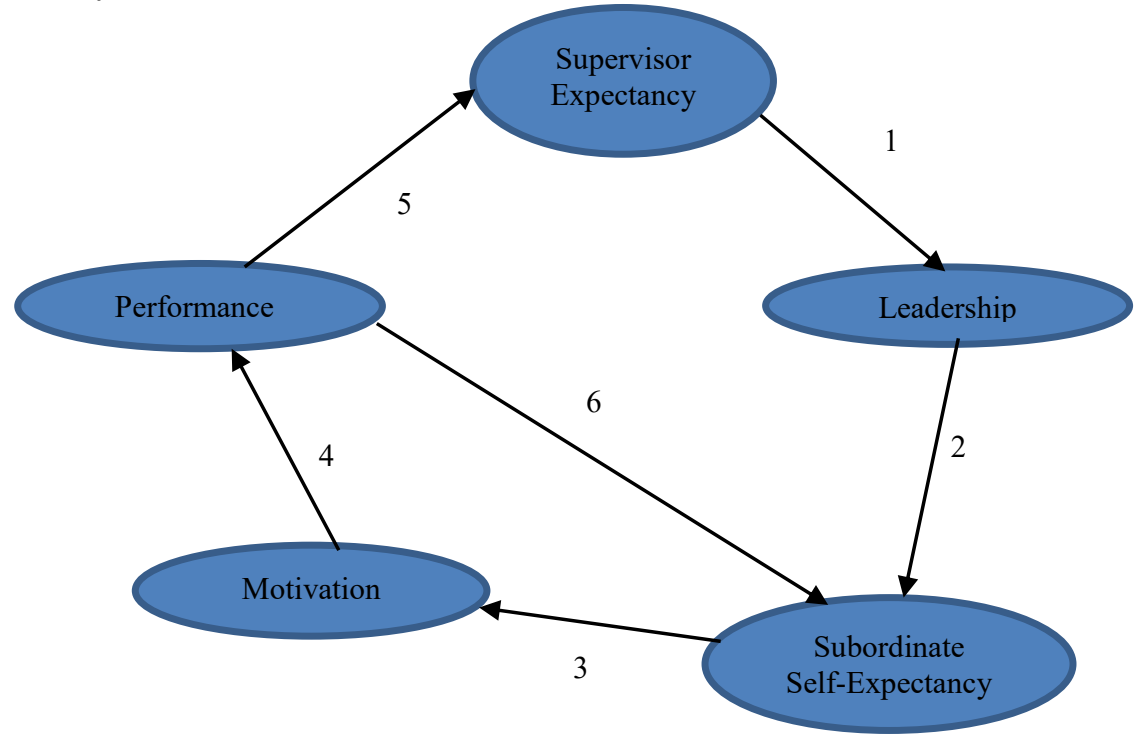

Figure 2. A Model of the Self-Fulfilling Prophecy at Work (Eden, 1984)

In business life, there is a relation between the expectations of managers, leadership, the expectations of employees, motivation and performance. Livingston (1969) put forward the following phenomena after a series of case studies:

- What managers expect from their inferiors and how they treat them influence the performance of and progress of inferiors to a large extent.

- One of the distinctive qualities of successful and effective managers is that they establish high expectations which can be met by their inferiors.

- Ineffective managers cannot create such expectations and therefore, the productivity of their inferiors suffers from this.

- Inferiors usually act in line with what they think is expected from them. 
There is a linear relationship between the expectations of a leader from his/her inferiors and the talents of the inferiors. Leaders with high expectations can distribute authority, and assign their duties (Whiteley et al., 2012). Both in business environments and in educational organizations, one of the key ways to ensure efficiency and productivity is to have positive opinions about personnel and students. In any organization, where manager has hard-working, productive and successful believes about the personnel and reflect the same on them, the personnel will also be productive. The vice versa is also correct. When a person is thought to be unsuccessful and lazy, and treated accordingly, it can be seen that the person in question will not perform effectively (qn. Aydoğan, 2003).

The difference between the employees who perform efficiently and those who perform inadequately is not how much they are paid, but how they are treated. All managers may learn how to treat their inferiors to create mutual expectation of high performance. The major principle within the pygmalion process is that the performance expectations of managers influence the performance of employees. Expectations are an important factor to influence the creativity of employees, and have a motivational impact that defines the direction and power of behaviors (Tierney and Farmer, 2004)

When foreign studies on the pygmalion effect are reviewed, although the studies addressing the effect of teacher's expectations on students in classroom environment as well as the studies aiming to define the pygmalion effect in businesses may be seen (e.g. Berlew \& Hall, 1966; Rosenthal \& Jacobson, 1968; Livingston, 1969; King, 1971; Korman, 1971; Spitz, 1999; Clemente, 2008; Jenner, 1990; Eden, 1982; jenner, 1982; Howe, 1975; Zanna et al., 1975; Chang, 2011) there is no domestic study carried out in the fields of business management and education. It is seen that the pygmalion effect, the importance of which has been proven by foreign studies, has not been studied in our country yet. Therefore, this is an important study as it is the first study conducted on Pygmalion effect in Turkey, and it will light the way for the studies on the same subject.

This study aims to identify the expectations of managers perceived by primary school teachers and how these expectations influenced them. Therefore, answers for the following questions have been searched:

1) Do the ideas of teachers on the pygmalion effect vary depending on such variants as gender, specialty and assignment?

2) Is there a relationship between expectations of school managers and teachers' perceptions of career and career ideas?

3) What do teachers think about the feelings they have when their managers have high expectations concerning their abilities and how this influences their work?

4) What do teachers think about the feelings they have when their managers have low expectations concerning their abilities and how this influences their work?

\section{Method}

\section{Research Model}

In this study, a mixed method using both qualitative and quantitative data has been applied. Johnson and Onwuegbuzie (2004) define mixed method studies as the combination of qualitative and quantitative research techniques, methods and approaches in a research. One of the major reasons for preferring a mixed method is that the deficiencies and weaknesses of a single method are resolved by other methods. The triangulation technique, which is a mixed method design, has been used. In this design, qualitative and quantitative data are combined, and analyzed at the same time. Data analysis is usually carried out separately, and the data are combined during the interpretation stage. The term combination, meaning the triangulation of the data, may be explained as the constitution of methods applied to discuss the connection of the data, identify whether they support each other, and examine some phenomena. Investigators prefer the mixed method in order to gather different types of data which relate to the same phenomenon, and increase the accuracy level of their judgment (Denzin, 1978; Mitchell, 1986; Jick, 1989; Patton, 1990; Creswell, 2003; Baki and Gökçek, 2012). The purpose is to ensure a diversification by applying more than one data collection method and analysis method, 
thus increasing the persuasiveness of results. In the quantitative part of the study, descriptive research method has been used, while in the qualitative part of the study, interview method has been applied.

\section{Study Group}

Easily accessible case sampling, which is one of the purposeful samplings ranking among the probability based sampling methods has been used in the process of determining the study group. In purposeful (judgmental) sampling, investigator decides who will be selected at his/her own discretion, and includes those who fit the purpose of study in the sampling. Through the method of easily accessible case sampling, the investigator gains speed and practicality. Because, he/she chooses a close and easily accessible case in this method (Şimşek and Yıldırım, 2011; Balcı, 2005).

The study group has been made up of teachers working at the schools administered by 25 managers mastering in a postgraduate program without thesis at the Education Management Inspection Planning and Economy Department of Firat University Institute of Education Sciences. 9 of the school managers work at primary schools, 12 of them at secondary schools, and 4 at state high schools. The scale has been applied to receive the opinions of 215 teachers working at the schools administered by these managers in 2013 - 2014 school year; while all of the 215 teachers have stated their opinions about the items in the scale, the two open-ended questions in the interview form have been answered only by 113 teachers. The demographic information of the teachers constituting the study group is presented in Table 1.

\section{Table 1}

The Demographic Information of Teachers

\begin{tabular}{llcc}
\hline Variants & & f & \% \\
\hline Gender & Male & 107 & 49,8 \\
& Female & 108 & 50,2 \\
Duty & Class teacher & 74 & 34,4 \\
& Branch teachers & 141 & 65,6 \\
Seniority & 0-5 year & 75 & 34,9 \\
& 6-10 year & 60 & 27,9 \\
& 11-15 year & 51 & 23,7 \\
& 15-20 year & 22 & 10,2 \\
& 21 year and above & 7 & 3,3 \\
\hline
\end{tabular}

\section{Data Collection and Analysis}

A likert-type five-point scale made up of 18 items was used by Priyabhashini and This (2005) in their own study. According to the validity and reliability analysis of the scale, Cronbach's Alpha coefficient was 0.86 , KMO value was $0.889(\mathrm{p}<0.001)$, and the rate of total variance defined was $43.68 \%$. Descriptive analysis method was used for the analysis of the quantitative data. The analyses of frequency, percentage, standard deviation, arithmetic mean, t-test and one way variance were carried out during the descriptive analysis. Apart from this, a regression analysis was applied in order to identify the relation between the first 4 items of the scale which aimed to define the effect and thoughts of managers on teachers and the latter 14 items that aimed to define the thoughts of employees on their occupations, performances and careers. The significance level was set as 0.05 .

In order to collect qualitative data, a semi-structured interview form comprising the questions "How would you feel if your manager had high expectations related to your talents? How would this influence your job?" and "How would you feel if your manager had low expectations from you? How would this influence your job?" were presented to the teachers. In the process of processing the qualitative data, the phenomenology design is used. It is aimed to acquire in-depth knowledge about cases where we are aware but have no in-depth knowledge (Doğan et al., 2013).

Content analysis was applied to the qualitative data. The basic process in the content analysis is the combination of similar data within the scope of specific concepts and themes, as well as the organization and interpretation of such data in a way that can be understood by readers. The main purpose of the content analysis is to reach the concepts and relations which can explain the data 
collected. In this way, it is tried to identify the data in hand, and discover the facts that may be embedded in the data (Yıldırım and Şimşek, 2011). All the answers given for the two open-ended questions were considered valid, and analyzed. These answers which took place in 113 interview forms were transferred to computer environment, and put through necessary statistical processes by means of a quantitative data analysis software. Themes were created in consideration of the answers given during the analysis, and common or similar opinions were included in these themes. Each theme was written as a clause of a common opinion. The following formula developed by Miles and Heberman (1994) was used in order to measure the reliability of the study: Agreement Percentage (P) $=$ Consensus $(\mathrm{Na}) /[$ Consensus $(\mathrm{Na})+$ Dissidence $(\mathrm{Nd})]$ x 100. In qualitative studies, reliability is considered to be ensured if the agreement percentage between the reviews of expert and the reviews of investigator is above $90 \%$. The consulted expert put only seven expressions into a category different from the investigators' choice. The reliability of the study was calculated as $\mathrm{P}=289 /(289+11) \times 100$ $=96 \%$. In order to indicate the recurrence frequency of the expressions themed during the content analysis, the frequency as well as percentage values of the expressions were calculated.

\section{Results}

Independent groups $t$ test was applied in order to take the opinions of the teachers about the pygmalion effect on them caused by their managers depending on the gender variant. The results are presented in Table 2.

\section{Table 2}

The T Test Results of the Opinions about Pygmalion of Teachers in Terms of Gender Variable

\begin{tabular}{lllllllll}
\hline Groups & $\mathbf{N}$ & $\bar{X}$ & sd & df & Levene & Sig. Level & t & Sig. Level \\
\hline Male & 108 & 3,87 &, 79 & 213 & 8,971 &, 003 &, 445 &, 657 \\
Female & 107 & 3,92 &, 54 & & & & & \\
\hline $\mathrm{p}<.05^{*}$ & & & & & & & &
\end{tabular}

According to the independent groups t-test carried out in relation to the items similar to the views including managers' expectations from teachers such as "My manager feels sure about my competency to perform my duties, My manager thinks that I have the competency to carry out teaching activities, My manager thinks that I have the necessary talents and skills for my work, My manager thinks that the personal features and skills that I have are important for our school." as well as the views including teachers' opinions about their own careers such as "I think I have the necessary talents and skills to progress in my career, I feel ready to undertake new tasks and responsibilities, I feel that I would be successful in my job and fit well" the female teachers presented positive opinion with $=3.87$ arithmetic mean, while the male teachers presented positive mean with $=3.92$ arithmetic mean. According to this result, it may be concluded that both male and female teachers think the expectations and thoughts of their managers had significant effect on their behaviors and performance.

Independent groups t-test was applied in order to define the teachers' opinions about the pygmalion effect in consideration of the duty variant. The results are presented in Table 3 .

\section{Table 3}

The T Test Results of the Opinions about Pygmalion of Teachers in Terms of Duty Variable

\begin{tabular}{lllllllll}
\hline Groups & $\mathbf{N}$ & $\overline{\mathrm{X}}$ & sd & df & Levene & Sig. Level & t & Sig. Level \\
\hline Class teacher & 74 & 4,01 &, 71 & 213 & 0,80 &, 17 &, 102 &, 78 \\
Branch teachers & 141 & 3,85 &, 66 & & & & & \\
\hline p $<.05^{*}$ & & & & & & & &
\end{tabular}

No significant difference was observed in the independent groups t-test carried out in consideration of the duty variant. When the arithmetic means were reviewed, it was seen that the 
teachers busy with primary teaching agreed 4.01 with these ideas, while the in-field-teachers agreed 3.85. Although there was no significant difference, the opinions of the in-field-teachers gave a lower result. Concerning this result, the effect of school managers on the primary school teachers can be explained with the fact that these teachers spend more time with their managers in the school environment compared to in-field-teachers.

A variance analysis was carried out in order to take the opinions of teachers in consideration of the length of service variant (Table 4).

\section{Table 4}

The Anova Test Results of the Opinions About Pygmalion of Teachers in Terms of Seniority Variable

\begin{tabular}{lccclccccc}
\hline Seniority & $\mathbf{N}$ & $\overline{\mathrm{X}}$ & sd & Source of Variance & Sum of Sequares & df & MS & F & p \\
\hline 0-5 year & 75 & 3,903 &, 558 & Between Groups. & 1,351 & 4 &, 338 & \\
6-10 year & 60 & 3,835 &, 721 & Within Groups & 98,092 & 210 &, 467 & \\
11-15 year & 51 & 3,976 &, 839 & Total & 99,443 & 214 & &, 723 &, 577 \\
16-20 year & 22 & 3,962 &, 401 & & & & & & \\
21 + year & 7 & 3,579 &, 971 & & & & & & \\
Levene= 2,642 & \multicolumn{2}{c}{$\mathrm{p}=0,035^{*}$} & & & & & & \\
\hline
\end{tabular}

$* \mathrm{p}<.05$

No significant difference was found between the opinions of teachers on the pygmalion effect in conclusion of the statistical analyses carried out concerning the length of service variant. When the arithmetic means were reviewed, it was seen that the teachers with 16-20 years of service length had the highest value $(=3,96)$, while the teachers with over 21 years of service length had the lowest value $(=3,58)$. With this result, it can be said that all the teachers having participated in the study think that their managers' thoughts and expectations from them affect their performances.

A regression analysis was carried out to identify whether the expectations of the school managers from the teachers had any effect on the performance and thoughts of those teachers regarding their own careers. The first 4 items of the scale aim to define the effect and thoughts of managers on teachers and the latter 14 items aim to define the thoughts of employees on their profession, performance and careers. The results of the regression analysis performed to define the relation between the responses of the teachers to the first 4 items and the following 14 items are given in Table 5.

\section{Table 5}

The effect of Manager Exceptations on the Teachers' Thoughts of Job and Career

\begin{tabular}{lcccccc}
\hline Predictor Variables & $\mathbf{B}$ & $\mathbf{R}$ & $\Delta R^{2}$ & $\boldsymbol{\beta}$ & $\mathbf{t}$ & $\mathbf{p}$ \\
\hline Manager expectations & .560 & .519 & .269 & .519 & 8.863 & $.000^{*}$ \\
Dependent Variable: The Thoughts of Job and Career & & & & & & \\
$\boldsymbol{R}^{2}=.269$ & $\mathrm{~F}=78,561$ & $\mathrm{df}=1 ; 213$ & $\mathrm{p}=0.000^{*}$ & & & \\
\hline
\end{tabular}

*p<.05

It is understood that the manager's expectations are a significant predictor of the teachers' perception of their profession and career and that it explains 51,9\% of the overall variance (Table 5). It is observed that there is a significant and linear relation between the manager's expectations of their employees and the employees' performances and thoughts on their careers $(F=78,561, p=0,000)$. It is further observed that the increase of the employees' performance and their career development depend on the expectations of their managers. The relation between the manager's expectations of his employees and employees' performance and their opinions on their careers is significant $(t=8,863$, $\mathrm{p}=0,000)$. This relation demonstrates how the manager's expectations of their employees affect the 
employees' performance. In other words, teachers' feeling their manager's trust in them and in their performance helps the teachers to form positive opinions and emotions about their careers. This could mean that the manager's expectations can be a predictor of the teacher's performance.

The qualitative analysis which is the second step of the triangulation technique was carried out with the method of content analysis concerning the open-ended questions prepared to obtain teachers' opinion. The statements of the teachers were classified by the themes to determine whether the manager's expectations of them affect them or not and if so, how and in which way they were affected. The opinions of the teachers about how their manager's low expectations related to their talents would reflect on their job given as a response to the questions "How would you feel if your manager had high expectations of you? How would that affect your job?" are listed in Table 6.

\section{Table 6}

The Opinions of the Teachers about Their Manager's High Expectations

\begin{tabular}{lcc}
\hline Effect & f & \% \\
\hline High expectations would affect positively & 94 & 83,19 \\
High expectations would affect negatively & 17 & 15,04 \\
High expectations not would affect & 2 & 1,77 \\
\hline
\end{tabular}

It is demonstrated in Table 6 that some participants stated that high expectations of my manager would affect me positively ( $\mathrm{f}=94)$, some stated that it would affect them negatively ( $\mathrm{f}=17$ ) and some stated that they would not be affected at all (2).

The majority of teachers $(83,19 \%)$ indicated that their managers' high expectations affected them significantly in a positive way. Such a high ratio as well as the low proportion of those who said that high expectations had negative effects $(15,04 \%)$ put forth the importance as well as the reality of the effect of high expectations.

The expressions of the teachers stating that "my manager's high expectations of me would affect me positively" and the frequency of these expressions are listed in Table 7.

\section{Table 7}

The Expressions of the Teachers Stating that "My Manager's High Expectations of Me would Affect Me Positively"

\begin{tabular}{lcc}
\hline High expectations would affect positively & f & \% \\
\hline It would leave a positive effect on me & 31 & 21,53 \\
I would like it and be happy & 18 & 12,50 \\
I would work harder & 17 & 11,81 \\
It would increase my motivation & 15 & 10,41 \\
I would work more eagerly and attentively & 14 & 9,72 \\
It would affect me positively if exceptations were as much as I could do & 12 & 8,33 \\
I would try to do as much as I can & 9 & 6,25 \\
The exceptations appropriate for education and training affect me positively & 8 & 5,55 \\
It would encourage me & 7 & 4,86 \\
It would show my manager trusts me & 6 & 4,16 \\
I would feel more responsible & 5 & 3,47 \\
I would be more successful & 2 & 1,39 \\
\hline
\end{tabular}

There were 144 positive statements in total in the responses. Teachers tried to express their manager's having a high expectation of them through sentences such as "It would affect me positively" ( $\mathrm{f}=31$ ), "I would like it and be happy" ( $\mathrm{f}=18$ ), "I would work harder" ( $\mathrm{f}=17$ ), "It would increase my motivation" ( $\mathrm{f}=15$ ). The phrase "I would be more successful" by the high expectations is given only by $\mathrm{f}=2$, but this does not mean that high expectations would not increase the rate of success; it is because the study data consists of the exact phrases of the teachers. When the essence 
and the meaning are reviewed, it is clear that the phrases consist of positive opinions including the expressions of being more successful, hard working, productive and happy individuals.

It is observed that the manager's high expectations of his employees are generally perceived positively by the teachers, high expectations make the employees feel better and trigger them to do their job better and to be more successful. Such expressions as "I will work more eagerly and harder" indicate that people's commitment and motivation have increased, so productivity and performance may build up, while expressions like "it has a positive effect, I would be happy" show that employees' feelings have been positively influenced, which will help them become self-confident, happy individuals.

The phrases of the teachers saying that "my manager's high expectations would affect me negatively" and the frequency of these phrases are listed in Table 8.

\section{Table 8}

The Expressions of the Teachers Stating that "My Manager's High Expectations of Me would Affect Me Negatively"

\begin{tabular}{lcc}
\hline High expectantions would affect me negatively & f & \% \\
\hline It would create uneasiness and anxiety & 6 & 26,08 \\
I would feel stress & 5 & 21,73 \\
It would affect me negatively & 4 & 17,39 \\
I would feel incompetent & 3 & 13,04 \\
I would feel under pressure & 3 & 13,04 \\
I would feel restless & 2 & 8,69 \\
\hline
\end{tabular}

There are 23 negative phrases in the responses of those stating "My manager's high expectation of me would affect me negatively". Participants also stated that "It would create uneasiness and anxiety (6)", "I would feel stress (5)", "I would feel under pressure" (3), "I would feel incompetent" (3) and "I would feel restless" (2).

The fact that phrases such as uneasiness, stress, pressure and inability are used is caused by the teacher's worries that they may not meet high expectations. The individual asks himself/herself the question "I wonder if...," does not find himself adequate in this subject. Here, the personal characteristics and occupational background of the individual step in, which indicate that the individual has some problems with his/her self-confidence.

The teachers' opinions on how their manager's lower expectations about their talent would reflect on their performance, concerning the questions How would you feel if your Principal had low expectations related to your talents? How would this affect your job? are listed in Table 9.

\section{Table 9}

The Opinions of the Teachers about Their Manager's Low Expectations

\begin{tabular}{ccc}
\hline Effect & f & $\%$ \\
\hline Low expectations would affect positively & 18 & 15,93 \\
Low expectations would affect negatively & 70 & 61,94 \\
Low expectations not would affect & 25 & 22,13 \\
\hline
\end{tabular}

The opinion that "My manager's having a low expectation of me would affect me negatively" $(\mathrm{f}=70)$ was more frequent among the teachers. 25 participant said that "My manager's having low expectation of me would not affect me". 18 among the teachers said "My manager's having low expectation of me would affect me positively."

It is demonstrated in Table 9 that the rate of those who stated their opinion as "low expectation would affect me negatively" is higher (70\%). The significant point here is that only 2 teachers responded as "high expectation would not affect me" (see Table 7), and yet those stating "low 
expectation would not affect me" is higher in number $(\mathrm{f}=25)$ (see Table 10). This means that there is a difference between participants' reactions to high expectations and low expectations. It is safe to say that participants are more affected by the high expectation.

The statements of those saying "my manager's low expectation would affect me positively" and the frequency of those statements are listed in Table 10.

\section{Table 10}

The Expressions of the Teachers Stating that "My Manager's Low Expectations of Me would Affect Me Positively"

\begin{tabular}{lcc}
\hline Low expectantions would affect positively & f & \% \\
\hline I would work harder & 1 & 77,78 \\
Low expections would make me more ambitious & 4 & 16,67 \\
I would get help from a more experienced teacher to develop myself & 3 & 5,55 \\
\hline
\end{tabular}

Among those saying "My manager's having a low expectation of me would affect me positively", 14 employees mentioned that "they would work harder". 3 employees said that low expectation "would make me more ambitious" and 1 employee said that "I would get help from a more experienced teacher to develop myself". Teachers stated that low expectations would trigger their ambition and thereby affect them positively, that they would try to challenge and refute such lower expectations, that they would be inclined to work harder to prove themselves.

The statements of those saying "My manager's low expectations would affect me negatively" and the frequency of these statements were listed in Table 11.

\section{Table 11}

The Expressions of the Teachers Stating that "My Manager's Low Expectations of Me would Affect Me Negatively"

\begin{tabular}{lcc}
\hline Low expectantions would affect negatively & f & \% \\
\hline I would feel bad, it would affect me negatively & 25 & 24,03 \\
They would fail & 12 & 11,50 \\
I would take a dislike to my job & 9 & 8,65 \\
My motivation would weaken & 9 & 8,65 \\
My performance would weaken & 9 & 8,65 \\
I would feel incompetent and incapable & 7 & 6,73 \\
My self-confidence would decrease & 6 & 5,76 \\
I would abandon trying & 6 & 5,76 \\
I would question myself & 5 & 4,80 \\
I would be unhappy & 4 & 3,84 \\
I would feel worthless & 3 & 2,88 \\
I would think he does not need to me & 3 & 2,88 \\
I would trust my manager less & 2 & 1,92 \\
I would ask to be reassigned & 2 & 1,92 \\
I would get angry & 1 & 0,96 \\
I would feel belittled & 1 & 0,96 \\
\hline
\end{tabular}

104 negative statements were found in the statements of the teachers saying "My manager's low expectations of me would affect me negatively". 25 participants used the phrases "I would feel bad, it would affect me negatively", and 12 participants said that "They would fail". Teachers used negative phrases such as "I would take a dislike to my job", "My motivation would weaken", "I would feel incompetent and incapable", "I would abandon trying", "I would question myself", "I would be unhappy", "I would feel worthless", "I would trust my manager less", as to confirm the negative effect of low expectations.

The negative aspects in the statements of those saying "low expectation would affect negatively" is significant. Teachers mentioned that they would experience challenges both in fulfilling their duties 
and at a more personal level. Phrases such as "I would feel belittled, I would feel bad, I would get angry" show that they would be affected negatively in a more personal level and phrases such as "I would fail, I would take a dislike at my job, I would abandon trying, and my performance and motivation would weaken" show that they would be affected in a professional level by the low expectations. Given the phrases such as "I would question myself, I would feel incompetent and untalented", we can say that employees start to suspect themselves and their professional performance when faced with low expectations. It even comes to mind that low expectations would cause them to feel themselves worthless and incompetent and thereby abandon trying to do better both in professional and personal terms. The use of the phrase "I would ask to be reassigned" leads us to believe that low expectations may affect the person so much that they consider changing their workplace.

\section{Discussion, Conclusion and Recommendations}

Every manager creates some expectations about employees. They convey these expectations to employees through verbal or non-verbal communication. Employees then, show a tendency to react and behave in line with these expectations that are expected from them. This study was performed with the aim of identifying the effects of manager expectations on employees in educational institutions; a scale and an interview form questioning the pygmalion effect were applied to teachers. According to the quantitative findings acquired as a result of the analyses carried out, it was confirmed that gender, assignment and seniority did not have any effect on teachers' opinions towards the pygmalion effect. Regardless of their gender, assignment and period of service, it was concluded that the participants think the expectations and thoughts of their managers had significant effect on their behaviors and performance. Besides, it was confirmed that managers' thoughts and expectations towards employees had positive effects on teachers' opinions about their profession, duty and career, and it became evident that teachers thought high expectations would bring forth an increase in their performance. In parallel to this conclusion, Korman (1971) carried out an experimental research named "Expectancies as Determinants of Performance" find an answer to the question "Are high expectations effective in enhancing the performance of underperforming groups?" and he discovered that high expectations enhanced performance. In their studies, Stedry and Kay (1966) found a relation between the expectations of managers and the performance of employees. For them, it was probable that managers' positive expectations would have positive effects, and negative expectations would have negative effects. Moreover, Eden and his students (1982) conducted studies in two different fields of Israel Defense Forces, and they observed improvements in the performances of the study groups compared to the control groups, concluding that high expectations resulted in higher performance (Eden \& Ravid, 1982; Eden \& Shani, 1982).

According to the findings acquired from the answers given by the teachers for two open-ended questions which were asked to them in the qualitative part of the study, employees stated that their managers' high expectations affected them positively to a large extent. The teachers indicated that their managers' high expectations affected them significantly in a positive way. Such a high ratio as well as the low proportion of those who said that high expectations had negative effects put forth the importance as well as the reality of the level of high expectations. It was seen that high expectations made individuals feel good and at the same time, prompted them to do their jobs better, and succeed. Such expressions as "I will work more eagerly and harder" indicate that people's commitment and motivation have increased, so productivity and performance may build up, while expressions like "it has a positive effect, I would be happy" show that employees' feelings have been positively influenced, which will help them become self-confident, happy individuals. In their article "A Teacher Expectation Intervention: Modelling The Practices of High Expectation Teachers" which supported these results revealing the presence of pygmalion effect, Rubie-Davies and her friends (2014) determined that teachers' high expectations from their students caused an increase in students' math scores. They confirmed that the success rate of students in the control group increased by $28 \%$ within one academic year. Apart from this, with the aim of determining how the expectations of students affect teacher performance, Feldman and Prohaska (1979) conducted an experimental study named "The Student as Pygmalion: Effect of Student Expectation on the Teacher." This experiment showed that students' expectations from a sufficient teacher rather than an insufficient teacher resulted in more 
positive behaviors, and affected high performance. This study indicates that, students' expectations from their teachers are influential.

The phrases like uneasiness, stress, pressure and inability used by the teachers as an emotional reflection of the managers' high expectations from them are caused by the teachers' worries that they may not meet high expectations. The individual asks himself/herself the question "I wonder if...," does not find himself adequate in this subject. Here, the personal characteristics and occupational background of the individual step in, which indicate that the individual has some problems with his/her self-confidence.

It was seen that the proportion of the individuals stating that low expectations had negative effects was higher. What is remarkable at this point is that individuals indicating high expectations do not have any effect on them are few in number; however, there are many individuals who state that low expectations do not have any effect on them. It is understood from this that there is a difference between employees' reactions to high expectations and low expectations. Supportively, McNatt (2000) concluded from his meta-analysis of 17 studies about pygmalion effect that the negative effects of pygmalion, meaning the effect of negative expectations and also defined as the golem effect, were more powerful when compared to the effects of positive expectations. Besides, this study has also demonstrated that men are more easily manipulated by expectations compared to women.

The negative aspects in the statements of those saying "low expectation would affect negatively" is significant. Teachers mentioned that they would experience challenges both in fulfilling their duties and at a more personal level. Expressions such as "I would feel belittled, I would feel bad, I would get angry" show that they would be affected negatively in a more personal level and expressions such as "I would fail, I would take a dislike at my job, I would abandon trying, and my performance and motivation would weaken" show that they would be affected in a professional level by low expectations. Given the phrases such as "I would question myself, I would feel incompetent and untalented," we can say that employees start to suspect themselves and their professional performance, which may cause them to accept everything as they come, and stop trying. The use of the phrase "I would ask to be reassigned" leads us to believe that low expectations may affect the person so much that they consider changing their workplace.

There were also those who stated that low expectations would trigger their ambition and thereby affect them positively, that they would try to challenge and refute such lower expectations, and that they would be inclined to work harder to prove themselves.

These findings acquired from teachers' views reveal the reality and accuracy of pygmalion effect in the field of education, and show that high expectations pave the way for teachers' motivation, effort, active working, commitment as well as the growth of their enthusiasm. It is seen that high expectations will generally reveal high performance, while low expectations, due to their negative effects on employees, will cause decrease in motivation as well as unwillingness towards the job being done and therefore, a decline or stability in performance.

\section{References}

Aydoğan, İ. (2003). Öğretim Ortamında Düşüncenin Gücü [The Power of Thought in Teaching Environment]. Afyon Kocatepe Üniversitesi Sosyal Bilimler Enstitüsü Dergisi [Afyon Kocatepe University Journal of the Institute of Social Sciences], 5(1), 200-222.

Balc1, A. (2005). Sosyal Bilimlerde Araştırma [Research in Social Sciences]. Ankara: Pegem A Publishing.

Baki, A. \& Gökçek, T. (2012). Karma Yöntem Araştırmalarına Genel Bir Bakış [An Overview of Mixed Method Research]. Elektronik Sosyal Bilimler Dergisi [Journal of Electronic Social Sciences], 11(42), 001-021.

Bezuijen, X.M., Ber, P.T., Dam, K. \& Thierry, H. (2009). Pygmalion and Employee Learning: The Role of Leader Behaviors. Journal of Management, 35(5), 1248-1267.

Berlew, D.E \& Hall, D.T. (1966). The Socialization of Managers: Effects of Expectations on Performance. Administrative Science Quarterly, 11(2), 207-223.

Bridge, B. (2003). Eğitimde Vizyoner Liderlik ve Etkin Yöneticilik. İstanbul: Beyaz Publishing. 
Chang, J. (2011). A Case Study of the "Pygmalion Effect: Teacher Expectations and Student Achievement". International Education Studies, 4(1), February.

Chirayath, S. Lalgem E. M. \& George, S.B. (2009). Expectations Come True: A Study of Pygmalion Effect on the Performance of Employees. Management and Labour Studies, 34(1), February.

Clemente, F. J. (2008). Effects of Teacher Expectations on the Development of Verbal Creativity in Childhood Education. Revista Electrónica Actualidades Investigativas en Educación, 8(3), 1-14.

Creswell, J. W. (2003). Research design: Qualitative, quantitative, and mixed methods approaches ( $2^{\text {nd }}$ ed.). Thousand Oaks, CA: Sage.

Demirtaş, H. A. (2004). Sosyal sınıflandırma, kişilerarası beklentiler ve kendini doğrulayan kehanet [Social classification, interpersonal expectations and self-verification prophecy]. Iletişim Araştırmaları [Communication Research], 2(2), 33-53.

Denzin, N. (1978). The research act: a theoretical introduction to sociological methods. $2^{\text {nd }}$ Edn. New York: McGraw-Hill

Doğan, S., Uğurlu, C.T., Yıldırım, T. \& Karabulut, E. (2013). Examining the communication process between school administrators and teachers according to the opinions of teachers. Turkish Journal of Education, 3(1), 34-47.

Eden, D. (1984). Self-fulfilling prophecy as a management tool: harnessing pygmalion. The Academy of Management Review, 9(1), 64-73.

Eden, D., \& Ravid, G. (1982). Pygmalion vs. self-expectancy: Effects of instructorand self-expectancy on trainee performance. Organizational Behavior and Human Performance, 30(3), 351-364.

Eden, D., \& Shani, A. B. (1982). Pygmalion goes to boot camp: Expectance, leadership, and trainee performance. Journal of Applied Psychology, 67(2), 194-199.

Eden, D., Geller, D., Gewirtz, A., Gordon-Terner, R., Inbar, I., Liberman, M., Pass, Y., SalomonSegev, I. and Shalit, M. (2000). Implanting pygmalıon leadership style through workshop traınıng: seven field experıments. Leadership Quarterly, 11(2), 171-210.

Feldman, R. S., and Prohaska, T. (1979). The student as Pygmalion: Effect of student expectation on the teacher. Journal of Educational Psychology, 71(4), 485-493.

George, A.S. (1982). Beyond pygmalion: Developments and directions in teacher expectations. Research South Pacific Journal of Teacher Education, 10(2), 41-49.

Howe, M.J.A. (1975). Pygmalion and after new research into teachers' expectations. Education 3-13: International Journal of Primary, Elementary and Early Years Education, 3(1), 46-49.

Jenner, H. (1990). The Pygmalion effect: the importance of expectancies. Alcoholism Treatment Quarterly, 7(2), 127-133.

Jick, T. D. (1989). Mixing qualitative and quantitative methods: Triangulation in action. Administrative Science Quarterly, 24(4), 602-611.

Johnson, R. B., \& Onwuegbuzie, A. J. (2004). Mixed methods research: A research paradigm whose time has come. Educational Research: Quantitative, Qualitative, and Mixed Approaches, 33(7), $14-26$

Kashen, D. (2011). Use the pygmalion effect to create a high performing team. http://awesomeculture.com/2011/10/03/use-the-pygmalion-effect-to-create-a-high-performingteam/. Downlanded at 02.01.2014.

King, S. S. (1971). Self-fulfilling prophecies in training the hard-core supervisors' expectations and the underprivileged worker's performance. Social Science Quarterly, 52(2), 369-378.

Korman, A. K. (1971). Expectancies as determinants of performance. Journal of Applied Psychology, 55(3), 218-222.

Şenlen, S. (2008). Bernard Shaw'in pygmalion adlı oyununda dil, eğitim ve toplumsal sınıf ilişkisi [Language, education and social class in bernard shaw's "pygmalion"]. Ankara Üniversitesi Dil ve Tarih-Coğrafya Fakültesi Dergisi [Journal of Ankara University, Faculty of Languages, History and Geography], 48(2), 29-41.

Livingston, S. J. (1969). Pygmalion in Management. Harvard Business Review.

Locke, A.E. \& White, S. (200). Problems with the pygmalion effect and some proposed solutions. Leadership Quarterly, 11(3), 389-415.

Loftus, P. (1995). The Pygmalion effect. Industrial and Commercial Training, 27 (4), 17-20 
Madran, H. A. D. (2012). Temel Beklenti Etkisi: Kendini Gerçekleştiren Kehanet [Basic Expectation Effect: Self-fulfilling prophecies]. İstanbul Bilgi Üniversitesi Yayınları [İstanbul Bilgi University Publications], 29-40.

McNatt, D. B. (2000). Ancient Pygmalion joins contemporary management: A metaanalysis of the result. Journal of Applied Psychology, 85(2), 314-322.

Merton, R.K. (1948). The self-fulfilling prophecy. Antioch Review, 8(2), 193-210.

Miles, M.B., \& Huberman, A.M. (1994). Qualitative data analysis: an expanded sourcebook. Thousand Oaks, California: SAGE. Morahan- Martin.

Mitchell, E.S. (1986). Multiple triangulation: A methodology for nursing science. Advances in Nursing Science, 8(3), 18-26.

Murphy, A., Campbell, C. \& Garavan, T.N. (1999). The Pygmalion effect reconsidered: its implications for education, training and workplace learning. Journal of European Industrial Training, 23(4), 238-250.

Patton, M. Q. (1990). Qualitative evaluation and research methods. (2nd ed.). Newbury Park, CA: Sage.

Prasad, D. (2013). The central theme of education in shaw's pygmalion. The Criterion an International Journal in English, ISSN 0976-8165.

Priyabhashini A, \& This V.R. (2005). Transformational leadershıp and follower's career advancement: role of pygmalion effect. Indian Journal of Industrial Relations, 40(4), 482-499.

Reynolds, D. (2007) Restraining golem and harnessing pygmalion in the classroom: a laboratory study of managerial expectations and task design. Academy of Management Learning \& Education, $6(4), 475-483$.

Rosenthal R. \& Jacobson L. (1968). Pygmalion in the classroom: teacher expectation and pupils' intellectual development. New York: Holt, Rinehart \& Winston, 1968. Pp. 240. [Harvard Univ., Boston, MA and South San Francisco Unified Sch. District, SanFrancisco, CA]

Rosenthal, R. and SL Jacobson, L. (1966). Teachers' expectancies: Determinates of pupils' IQ gains. Psychological Reports, 19, 115-118.

Rubie-Davies, C., Peterson, E.R., Sibley, C.G. \& Rosenthal, R. (2014). A teacher expectation intervention: Modelling the practices of high expectation teachers. Contemporary Educational Psychology, 40, 72-85.

Shaw, B. (2004). Pygmalion. Contans Ontarı Currıculum Support Materıal. Study Guide. Londra

Spitz, H.H. (1999). Beleaguered pygmalion: a history of the controversy over claims that teacher expectancy raises intelligence. Intelligence 27(3), 199-234 Princeton, NJ, USA.

Stedry, A. C. \& Kay, E. (1966). The effects of goal difficulty on performance. Behavioral Science, $11(6), 459-470$.

Tierney, P. \& Farmer, S.M. (2004). The pygmalion process and employee creativity. Journal of Management, 30(3), 413-432.

Wang, L. (2000). The upward pygmalion effect in the organization. Masters Theses \& Specialist Projects. Western Kentucky University, Paper 707.

Whiteley, P., Sy, T. \& Johnson, S.K. (2012). Leaders' Conceptions of Followers: Implications for Naturally Occurring Pygmalion Effects. The Leadership Quarterly, 23(5), 822-834.

Yıldırım, A. \& Şimşek, H. (2011). Sosyal bilimlerde nitel araştırma yöntemleri [Qualitative research methods in the social sciences], (8. Press). Ankara: Seçkin Publishing.

Zanna, M.P., Sheras, P.L. \& Cooper, J. (1975). Pygmalion and galatea: the interactive effect of teacher and student expectancies, Journal of Experimental Social Psychology, 11(3), 279-287. 